\title{
Criptococose Cerebral em Paciente Imunocompetente: Relato de Caso
}

\author{
Sobreira, M.S.; Braz, M.S.; Friske, C.D.; Winckler, J.L.; Seidl, D.S.; Cappellari, \\ N.F.; Mengue, C.S.; \\ Apresentador: Mateus Silva Sobreira
}

\section{Resumo}

Introdução: O Cryptococcus sp é a principal micose que atinge o sistema nervoso central (SNC). A meningoencefalite é a forma clínica mais comumente diagnosticada, ocorrendo em mais de $80 \%$ dos casos. A infecção primária ocorre por inalação, e nos pulmões, a doença é, via de regra, assintomática e de resolução espontânea. Contudo, pode haver disseminação hematogênica para o SNC. O objetivo deste relato de caso é descrever um caso de criptococose cerebral em um paciente imunocompetente e a conduta médica frente ao caso, em vista de poucos casos descritos na literatura. Método: Foi selecionado para este trabalho um paciente adulto, jovem, de 34 anos, imunocompetente, do sexo feminino, com diagnóstico confirmado de criptococose cerebral, a qual foi internada no Hospital Universitário ULBRA-Canoas em Agosto de 2013, após ser transferida do Hospital de Pronto Socorro de Canoas. Os dados apresentados consta do prontuário da paciente. Resultados: A paciente procurou atendimento médico queixando-se de cefaleia e ptose palpebral. Através de anamnese e exame físico foram constatados, também, a presença de anisocoria, rigidez de nuca, confusão mental, náusea, vômitos e manchas acastanhadas em membros inferiores. Realizou-se punção lombar (mostrou alta pressão de abertura) para análise do líquor cefalorraquidiano (revelou pleocitose com predomínio de linfócitos, glicorraquia e protéinas elevadas). Tomografia computadorizada sem contraste e Ressonância Magnética revelaram redução da amplitude dos ventrículos laterais e grosseiras calcificações em núcleos da base bilateralmente (achados sugestivos de processo inflamatório fúngico). Além desses foram realizados cultura do líquor (positivo para Cryptococcus) e Anti-HIV Elisa (negativo em 3 testes). Em razão de piora clínica, paciente é transferida para a Unidade de Terapia Intensiva (UTI), onde é usada terapêutica de fluconazol com anfotericina B (3 ciclos de 15 dias). Paciente recebe alta após 75 dias em UTI, com sequélas (cegueira, dificuldade de deambulação e déficit cognitivo). Conclusões: O tratamento de criptococose cerebral em pacientes imunocompetentes é uma questão desafiadora por inúmeros fatores, sendo um deles a pouca quantidade de literatura sobre o assunto. O paciente deste caso apenas evoluiu para melhora com a introdução de fluconazol no esquema terapêutico, o que corrobora ser este antifúngico uma boa terapia para casos selecionados como outras evidências também demonstram.

\section{Referência:}

Sobreira, M.S.; Braz, M.S.; Friske, C.D.; Winckler, J.L.; Seidl, D.S.; Cappellari, N.F.; Mengue, C.S.;. Criptococose Cerebral em Paciente Imunocompetente: Relato de Caso. In: II Congresso Brasileiro de Medicina Hospitalar - II CBMH [= Blucher Medical Proceedings, vol.1, num.5] São Paulo: Editora Blucher, 2014. p.45

DOI 10.5151/medpro-II-cbmh-039 